\title{
SPECIFIC AND DIFFERENTIATED EDUCATION: cultural complexes of the Haliti-Paresi mother tongue
}

EDUCAÇÃO ESPECÍFICA E DIFERENCIADA: complexos culturais da língua materna Haliti-Paresi

EDUCACIÓN ESPECÍFICA Y DIFERENCIADA: complejos culturales de la lengua materna Haliti-Paresi

\section{Waldinéia Antunes de Alcântara Ferreira \\ Professor at the State University of Mato Grosso. PhD in Education from UFRGS. Pedagogical Coordinator of the Intercultural Pedagogy course-FAINDI-Unemat- Campus of Barra do Bugres-MT. Professor of the graduate programs in Education-PPGEdu and Master in Teaching in Indigenous Intercultural Context- PPGECII. waldineiaferreira@unemat.br. \\ 0000-0001-5949-7590}

\section{Nilce Zonizokemairô}

Master's student of the Strictu Sensu graduate program Master in "Teaching in Indigenous Intercultural Context". Professor at the Zozoiterô Indigenous Municipal School.

\section{0-0001-7657-1027}

Correspondence: Zozoiterô Indigenous Municipal School - Aldeia Rio Verde- CEP 78300-000, Tangará da Serra-MT-Brazil.

Received: 10.12 .2020

Accepted: 11.20 .2020 .

Published: 01.01.2021.

\begin{abstract}
:
This article presents some reflections related to mother tongue teaching with the Haliti Paresi people. It is the result of some questions raised from the classes at the Post-Graduation Stricto Sensu Professional Master in "Teaching in Indigenous Intercultural Context" - UNEMAT, about significant pedagogical practices within the context of the specific, differentiated, intercultural and bilingual school. It addresses the place of the mother tongue in the school and its cultural complexes constituted by stories, memories and its own culture. Localizes the mother tongue as a language of instruction at school, as a linguistic ethnopolitics and as a fundamental factor of ethnic identity.

KEYWORDS: Mother tongue; Haliti-Paresi; Culture.
\end{abstract}

\section{Introduction}

We present, in this textual construction, a reflection made in dialogicity, between author and co-author, about the native language Haliti Paresi as a Pedagogical Practice. These are reflections undertaken in the Stricto Sensu Graduate Program Professional Master in "Teaching in Indigenous Intercultural Context" - UNEMAT. This dialogue was justified mainly on the experience of the co-author, guided by other dialogues carried out in the Aldeia Rio Verde of the Haliti-Paresi people. Therefore, it consists of a text built on learning and exchanges, compositions shared in listening to one another.

We bring, at first, the Haliti-Paresi, a strong people who share Brazilian territory with many other ethnic groups. An indigenous people like so many others in Brazil, who have an original mother tongue, their own identity, a people who challenge the continuity of being indigenous, of being Haliti-Paresi.

It is known that at the beginning of colonization there was, in Brazil, a very large linguistic variety, but that 'colonization', a phenomenon that created racialization in America and subordinated the original peoples, was responsible for several genocides, among them, the linguistic. According to Seki (1999), nowadays, there is an estimate that 
about 180 indigenous languages are still spoken in Brazil, however, many more were spoken. The studies produce an estimate that, since the arrival of the Portuguese people, it is possible that at least 1,000 languages have been lost. The languages spoken are "distributed in five major groups: Tupi Family, Family Macro-Jê, Family Karib, Family Aruak, Family Pano, with nine other smaller families and ten linguistic isolates" (p. 259).

Although this estimate is presented in research, it cannot be forgotten that these indigenous languages continue to be threatened, suffering impacts resulting from contact with the Portuguese language, that is, the majority language of the country.

In Brazil today, Aruak language speakers are distributed from the border with Guyana to the state of São Paulo. In the State of Mato Grosso, their linguistic relatives are the Enawene Nawe, who live in the region between the Juruena River and the Serra do Norte; the Waurá, the Mehinako and the Yawalapiti of the Upper Xingu and the Terena of the Gleba Iriri Indigenous Land. (Haliti -Paresi, 2019)

Thus, the Haliti-Paresi people speak the Aruak language family and they are in the State of Mato Grosso, located in nine Indigenous Lands: Paresi, Utiariti, Rio Formoso, Juininha, Estivadinho and Figueiras already approved and demarcated; the Uirapuru, Ponte Pedra and Estação Parecis Indigenous Lands which are in the process of demarcation. These lands occupy the geographical spaces of the towns: Tangará da Serra, Sapezal, Campo Novo do Parecis, Conquista do Oeste, Barra do Bugres, Campos de Júlio, Nova Lacerda, Diamantino and Nova Marilândia. Currently, the current population accounts for 2,186 inhabitants.

The Paresi Indigenous Land has an extension of 563,586 hectares, it is located in the town Tangará da Serra-MT, highlighting that 52 percent of the town is indigenous land. The village Rio Verde, which is the locus of insertion of the school under discussion, belongs to the town Tangará da Serra-MT, where 21 families live, with a population of 65 people.

The mother tongue is very important for a people, it is the essence of interaction and communication between peoples, it is the link and cultural strengthening of a given society, as it is very important in socio-cultural manifestations, that is why, it symbolizes the identity of a people.

In the case of the Haliti-Paresi people, there is a concern on the part of elders and traditional leaders with the mother tongue today. This concern is about the preservation, valorization and strengthening of the mother tongue that runs, like many other native languages, the risk of disappearing. This hypothesis of threat of disappearance is the result of several aspects that, over time, have been causing socio-cultural impacts and 
transformations in Haliti Paresi society. The disappearance of the mother tongue and, at the same time, the threats, in some way, impact the people, including the issue of religiosity and spirituality, which has a very strong connection with the mother tongue Haliti Paresi. Such elements have "in the mother tongue the expression of their ethnic identity (affirmation of the Paresi themselves)" and (PAES, 2002, p.52). Although they have intense contact with non-indigenous society, the maintenance of their mother tongue is the maintenance of being Paresi.

The mother tongue is fundamental for the survival of the Haliti Paresi community as an indigenous people, it is the defense of the people, considering that it is also a traditional knowledge, explains Nazokemai (2018). It is one of the most important elements of the cultural identity of an indigenous people, a knowledge that comes from the ancestors. Through their mother tongue, the Haliti-Paresi people have been strengthening and valuing their spiritual essence and culture, learning to value the ancient knowledge of their people. They continue to pass on this knowledge through their mother tongue to the new generations, so that they never forget their culture and the values of the Haliti Paresi indigenous people.

Within this context, the meaning of the mother tongue, it is possible to ask: Are all Haliti-Paresi, from the territories of this original people, speakers of the original language? About this, it can be said that history has silenced many Haliti, resulting in a sociolinguistic reality that differs between villages and within subgroups.

The Haliti-Paresi Management Plan (2019) points out that, today, there are representatives of the subgroups Kozarene, Waymare, Katxiniti, Warere, Kahete and Enomaniyere, the latter not registered in the historical bibliography on the Haliti".

However, according to Nilce Zonizokemairô, there are two subgroups Haliti Paresi, Kozarene and Waimare that have a large number of representatives and, with regard to the sociolinguistic situation, the Kozarene subgroup, the vast majority, at least $90 \%$, are speakers of the mother tongue. Children learn to speak the language when they start to understand and learn something about the culture, the life of Haliti-Paresi. Parents and family have an obligation to teach their children their mother tongue.

Even though a large part of the Kozarene are speakers, there are concerns, since every native language is in constant threat. Thus, one of the concerns at the present time, in the village of Rio Verde, with the Kozarene subgroup, concerns the influence of nonindigenous people (evangelical mission), who may, over time, interfere in the mother tongue of future generations.

In the Waimare subgroup there are few people who speak the original language, children, adolescents, young people and adults only speak the Portuguese language in 
their daily lives, and all of this has been happening due to miscegenation between people. These situations of contact with imuti (non-indigenous) have had an impact on the issue of the mother tongue, because who knows how to speak can no longer pass this knowledge on to the younger generation. Often, some young people are ashamed to learn and also to speak in their own mother tongue. On the other hand, parents and family are no longer able to teach their children, thinking that the Portuguese language is more important than the original language, even if that is the language used in the manifestation of the sacred.

These reasons justify the need for the indigenous community of the Haliti-Paresi people to take on an ethno-education and differentiated education in the sense of including their mother tongue as ethnopolitics or as an ethno-educational policy. In this sense, it is "ethnopolitical, because it says about the people themselves, in a state of reflection and memory" (FERREIRA, 2020, p.69) and, also, because it takes on the principle of decoloniality. It is also characterized as ethno-education, because it comprises ancestral and trans-generational education, therefore, ethno-educational policy.

In this perspective, as a linguistic and decolonial policy, the Haliti of the Rio Verde village, located in Terra Indígena Paresi, in Tangará da Serra-MT, have assumed the construction of a differentiated school, where knowledge and culture, starting with their own people, are valued and included (when possible) in the school curriculum. Let it be a schooled education, according to the struggle of the original peoples and legal advocacy, a community school education, specific, differentiated, bilingual or multilingual. It must be a schooling constituted within a dynamic in which the school is an instrument, an institutional environment that means cultural and social approaches, being an intra and intercultural process that strengthens what is their own, and also allows access to other knowledge, called 'universal'.

In this sense, there is an effort in the construction of a schooled education that contemplates the pedagogy of the Haliti-Paresi people, because it is understood that the indigenous school education has the fundamental role of being meaning, passing on, strengthening and valuing the knowledge and knowledge Haliti-Paresi people. There is a need for a school that assumes the recognition of diversity, of culture itself, and of language as an identity vehicle, with a view to maintaining it, appropriating it in the school space as a discipline, content, graphics, literacy and indigenous literacy. A school that currently experiences pedagogically the effective constitution of a specific and differentiated schooling education, a construction that is based on the memory, on the incarnated pains of the people regarding the stories learned with the elders about the first contacts with the immut and with the dominant teaching-learning process, in the 
silencing and annulment of the identity and the mother tongue, but also in the learning of writing in Aruak. They are complexes that become entangled in senses and feelings, conflicts and maintenance of the original language, because it is its own, ancestral and identity.

Therefore, building a different, specific, differentiated, intercultural and bilingual school education led by the Haliti-Paresi people themselves goes through the struggles of the indigenous movement, in the search for the guarantee of alterity and the appropriation of the school context, from the perspective of ethno-education produced in interculturality. A learned and critical interculturality because transformations are expected in the context of indigenous and non-indigenous societies, as the school is an ethnic border field, even though it is within the villages.

In this way, the indigenous school is the movement of intra and intercultural appropriation, where the school uses the 'pen', an object that produces writing that benefits - in the sense of the law - whether or not the original peoples. The pen represents writing in many aspects, which are found in the field of justice and access to rights for indigenous peoples, which have often been denied. It also represents the production of stories through the eyes of the colonizer, but it is also necessary to recognize that through it they produced analyzes and decolonial constructs. The original peoples also want it under your care in order to write their own history to access justice and rights. This ethnopolitical will is evidenced in the words of Professor Lino Zokenazokae when he says, "in the past we used the bow and arrow. Today we changed the bow and arrow and defended our rights at the tip of the pen "(Haliti - Paresi, 2019, p. 140.). There we have a metaphor for the domination of the object, of the elements that make up the nonindigenous world. Thus, exchange does not mean leaving your culture, but in movement, assuming the posture of marble and myrtle, according to Viveiro de Castro (2002), when he writes about the inconstancy of the wild soul. That is, the exchange exists when it is necessary to make it, but, later, the objects proper to the culture are resumed. So, as well, it is the school, a place of movement and different exchanges, the specific and differentiated school.

\section{Historical entanglements of the narrative about specific and differentiated education in the context Haliti Paresi}

The construction of indigenous school education, as sought by the original peoples and, in this case, by the Haliti Paresi people, results from a complex of memories, experiences embodied in painful and emancipatory learning that are part of a pedagogical continuum that occurs, even in the today covered with the cultural 
protagonism of the Haliti-Paresi. Thus, the reflection of this textual part has the purpose of producing an approximation, albeit descriptive, with a historical period of Brazilian education itself, of the school institution and, a few notes on the schooling of the Haliti Paresi people, mainly, regarding the language maternal.

It is known in the history of Brazilian education that the purpose of the school institution, for indigenous peoples, had as its first objective, to be an integrating vehicle for indigenous populations with non-indigenous society. Thus, the original languages were obstacles in this integrating process and the school, historically, took the responsibility of teaching the Portuguese language. So, it was the project of the Portuguese government to expand the use of the Portuguese language, to strengthen the State, to insert Indians into colonial society. And the school was one of those instruments within this panorama, initially, together with the company of Jesus who developed the work of teaching the Portuguese language, catechesis and the conversion of indigenous populations, afterwards, the company is expelled from the Brazilian colonial territory.

The Jesuits are remoted; however, there is a colonizing continuum, political organizations of subordination and assimilation in process, intensified with contacts with the non-indigenous, for the Haliti with the Imuti.

According to Paes (2002), the history of schooling with the Haliti Paresi people occurs around 1920, a time when Marechal Rondon coordinated and monitored the installations of the telegraph lines and, also, the period of the foundation of the Utiariti boarding school. It was a school with a rigid, militaristic, positivist system, with a proposal to produce training that would meet the integration of indigenous people into national society, mainly as citizens to defend Brazilian borders, as well as to serve society as workers, therefore, the major objective was integration into national society as workers (Pivetta, 1999).

The Utiariti boarding school later came to be managed by the Jesuit mission and was constituted under the aegis of colonialist models; one that met the objectives of the SPI - Indian Protection Service, that is, integrationist objectives and the other, based on the management of the Jesuits, between 1935-1970, making "[...] the transformation of pagans into Christianized citizens and national workers" (PIVETTA, 1999, p. 88).

The boarding school introduced the Portuguese language and its main function was to teach indigenous students to speak and read and write in Portuguese. Then, with the creation of FUNAI, in 1967, assuming school education in the villages, it created a policy of writing the original language. To this end, the country partners with the evangelical missionary agency Summer Institute of Linguistics (SIL) which aimed to develop literacy materials for various indigenous peoples in the country. "According to Funai's ordinance 
of 1972, the rule to be followed when creating alphabets for schools would be: "for each phoneme, a single symbol "(BARROS, 2004, p.) Thus, the education program of the SIL in Brazil. Among the many materials produced, there is a dictionary of the Haliti-Portuguese language of the Haliti-Paresi people and the Bible written in the mother tongue.

It is important to highlight that, in 1973, the Statute of the Indian was created, Law $n^{\circ} 6001 / 73$ and, in this, the norms regarding literacy of the indigenous people appear. According to the Statute in its Art. 49, "the literacy of the Indians will be done in the language of the group to which they belong, and in Portuguese, safeguarding the use of the first" (BRASIL, 1973).

And more recently, the 1988 Constitution, brings an approach not only of the mother tongue, but the protection of culture, of the proper ways of doing, learning, living, which refer to indigenous knowledge:

$210 \S 2^{\circ}$. Regular elementary education will be taught in Portuguese, indigenous communities also ensuring the use of their mother tongues and their own learning process.

Art.215: The State will guarantee everyone the full exercise of cultural rights and access to the sources of national culture, and will support and encourage the valorisation and dissemination of cultural manifestations.

$\S 1^{\circ}$. The State will protect the manifestations of popular, indigenous and Afro-Brazilian cultures, and those of other groups participating in the national civilization process.

Art. 231 The Indians are recognized for their social organization, customs, languages, beliefs and traditions, and the original rights over the lands they traditionally occupy, and the Union is responsible for demarcating, protecting and ensuring respect for all its assets.

There is with the Federal Constitution of 88 , the result of many struggles, including, of the original peoples, legal certainty regarding the recognition of ethnic diversity, specificity in the different constitutions, specific to each people. But, still in the late 1980s, it is the town Tangará da Serra that does the school management of indigenous schools, implementing the same guidelines and pedagogical practices as other elementary schools (PAES, 2002). In other words, the specific forms of learning, the specificity, the difference and even the mother tongue seem to have little or almost no presence in this educational environment.

Grando (2000) points out that schooled education, in indigenous areas in Brazil, is divided into phases. Thus, in completeness with the previous discussion, we present that the first phase is religious education that sought the conversion of the indigenous (colonial period); the second is marked with the creation of the SPI, from 1910, as already 
mentioned, positivist, with a rigid structure; then it is replaced by the National Indian Foundation-FUNAI. It is also in this second phase that the Summer Institute of Linguistics (SIL) appears. The third phase began in the 1970s, a period in which there was an organization of the indigenous movement and the emergence of indigenous practices with the participation of indigenous people and non-governmental organizations, a period of struggle for territories.

According to Grando (2000), there is the development of articulated educational work, where the struggle takes place in ensuring access to the right to indigenous territory, health and culture. This struggle, together with the indigenous people of the country,

[...] the Indian Missionary Council (CIMI), Operation Anchieta (OPAN), the Prolndio Commission (CPI), the Ecumenical Documentation and Information Center (CEDI), among others. At this stage, the Indigenous Movement joins other social movements in the country. This period of history was marked by the struggle of the social segments oppressed by the current system (GRANDO, 2000, p.73).

This movement emerged in the 1980s, not only in Brazil, but also in other countries with the recognition of a specific modality of education. In Brazil, with a specific, differentiated, intercultural and bilingual/monolingual indigenous school education. According to Monte (1997), in Brazil, this specificity is called bilingual intercultural education and in other Latin American countries it is called ethno-education.

There was, therefore, a national movement in the 1980s, extending to the later decades, in the search for the implementation of an indigenous school education that met ethnic specificities, that really recognized the diversity and otherness of indigenous peoples. It is important to remember that it was only in 1991 that school education in the villages became the responsibility of the Ministry of Education.

In this construct, or in this entangled complex, and with the perspective of having a school that could handle the construction of indigenous pedagogies, it was also necessary to fight for specific training for indigenous educators. And it is in this context that HalitiParesi, in the State of Mato Grosso, participated, since 1996, in the Tucum Project Program for the Training of Indian Teachers for Intercultural Teaching, which ended in 2000. The project was based on the valorization culture, land and language (Paes, 2002).

The Haliti-Paresi people participated in other intercultural formations, such as the Hayo project, Third Indigenous Degree of the State University of Mato Grosso, currently, Intercultural Indigenous Faculty that has the function, from specific courses, to promote the training of indigenous teachers of the State And, more recently, from the Stricto Sensu 
Graduate Program Professional Master in "Teaching in Indigenous Intercultural Context"

- UNEMAT. All of these formations are the result of indigenous struggles.

According to the Haliti-Paresi, the specific and differentiated school is dreamed of by the people, it is thought of an intercultural school proposed by the Federal Constitution of 1988 , with respect to the people, culture, customs and the mother tongue.

In these terms, the indigenous school must in fact be built in the process, in a decolonial way, an action that is daily and objective. It needs to be seen as a differentiated and specific public policy, a policy in which indigenous teachers are valued, because what happens is that there is a precariousness of the work of indigenous teachers. It is necessary for the law to actually produce didactic material that knows the original peoples in their specificities. The reality of the Haliti-Paresi people is that there is no support from the government or even production of these materials. However, there is a constant practice among educators, which is intracultural research and the production of written materials that help ethnopolitics and linguistic politics. It is a pedagogical experimentation in which the Haliti-Paresi takes on the self-teaching of writing and teaching the mother tongue within the possibilities created, however, still far from the dream, mainly, with regard to the publication of their own specific and differentiated material (printed).

\section{Mother tongue in school: incarnated cultural complexes}

The teaching of the mother tongue in indigenous schools aims to enhance and strengthen the native language of a specific people. So it is for the Haliti Paresi people.

The mother tongue is useful to communicate, express, register, recognize and reflect on the difference in 'dialect' between the subgroups, according to Haliti Paresi. In this perspective, the dialect is understood as a linguistic variation between the subgroups. These variations exist as a result of the subgroup, that means, it is a cultural characteristic of the communication context. This variation is admited by the subgroups and the mother tongue worked at school respects this specificity.

The discussion that follows presents the organization of a pedagogical practice of intra and intercultural education, that is, an ethno-education at the Zozoiterô Indigenous Municipal School that we consider, from our evaluations and didactic-pedagogical constructs, to be specific, differentiated and bilingual. It is a locus of schooled education based on the reality of the Haliti Paresi indigenous people, it is also intercultural because it embraces other cultures and it is related to the knowledge and dialogue between indigenous and non-indigenous culture, in this way, often facing the challenge of asymmetric power relations on the western side. 
It is important to emphasize that, according to Paes (2002), since 1999, the HalitiParesi group of teachers adopted a posture of being the protagonists of the pedagogical conduct in the school, including, inserting elements of culture in the school curriculum, as well as, for lack of specific teaching materials, adapt the books of the National Textbook Program to the reality of the Haliti-Paresi people.

There is a mother tongue discipline in the curricular organization and this is present at all levels of education and serves for studies related to language writing, since in Aldeia Rio Verde (the place we speak of) children, young and old are speakers.

The teachers Haliti Paresi agree that the discipline of Mother Language is one of the places in the curriculum that can be used to transmit the mythology of the ancestors, the traditional knowledge of the people, the socio-cultural and environmental sciences. Thus, the mother tongue discipline works on the social organization of the people, cultural, ethnic and linguistic values and everything that is part of the daily life of children and young people in the village, such as solidarity, justice, union, politics, traditional rituals, in short, the traditional Haliti Paresi culture is used. Thus, the content of the course is mainly composed of the cosmology and worldview of the Haliti-Paresi people.

It is still the goal of the discipline and even of the community that the Haliti Paresi indigenous child and youth are able to understand that the use of their mother tongue is a means of communication and expression of the thoughts and feelings of the people and the people. It is also necessary to recognize and value the linguistic diversity that exists between the Haliti Paresi subgroups and understand how and why writing in the mother tongue emerged in the Haliti Paresi society.

Considering the scope and philosophical complexity of thinking about the purposes of the Maternal Language subject, it is possible to express that the meanings of not only speaking, but spelling Aruak, is an ethnopolitical decision with a practice that is part of intercultural and even intracultural education. When referring to this subject, we infer the feelings and narratives, as well as the dialogues within the community with educators, leaders and elders, showing that the objective of teaching the mother tongue is a form of defense, considering that the language is also traditional knowledge of the people. Through it, one can access, not only the indigenous locus, but communication, traditional rituals, ethnopolitics, the social policy of the immuti, social justice and human rights. We know that the native language for the Imuti refers to the identity of Haliti Paresi, becoming an element of great importance in the struggle of indigenous peoples.

The teacher Ângelo Kezomae, says that teaching mother tongue in school is essential for strengthening culture in general, and also the importance of recording through writing everything that is told in the 
oral language by the elders. In the opinion of Willian Mars Cristiano Nazokemai, the mother tongue is the essence of the traditional communication of the Haliti Paresi people; of the school is to strengthen and value the language and traditional knowledge, also to learn the spelling of the mother tongue through writing, that is why it is important to teach the mother tongue within the indigenous schools for the children's learning. (KEZONAZOKERO, 2020, p. 29)

Thus, we reaffirm that the subject in its complexity and the learning of writing in Aruak, is a linguistic ethnopolitical movement, which occurs in two critical intracultural and intercultural movements.

The first, intracultural moves in the direction of the Haliti-Paresi cosmogony, with objectives aimed at the people, in the teaching of orality, traditions, the meanings of rituals, based on ancestry that respond to the people themselves, the incarnation of being Haliti-Paresi.

According to Martins (2018), intraculturality is a process in which there is an ethnically recognized and recognized ethnically substantiated by ancestral memories and histories. It is also a foundation for the search for struggles, resistance; it is the combination of two factors, one is internal and concerns its own traditions and the other is external, mediated by the characteristics of the Brazilian and Latin American indigenous society.

Thus, it is a phenomenon in which the historical awareness is made in the recognition of identity, within the social and historical relations experienced by the respective people. Marín (2014) explains that awareness is paramount so that people can understand the present experience, their daily lives and past and current conflicts, and through it - historical awareness - it is possible to predict a future ethnopolitics. In other words, it opens up the possibility of carrying out an analysis in which one recognizes oneself ethnically to build the figure of the other, using dialogicity and implementing interculturality.

An interculturality that is critical, that is oriented towards a democratic, plural and human construction of societies, articulating equality policies with identity policies (Candau, 2008). In this perspective, the mother tongue takes the place of ethnic recognition, both for indigenous peoples and for national society.

In the intracultural sense, we ask: what does it take to teach the mother tongue in the community of the Haliti-Paresi people? Thus, it is a consensus that, first, he is a HalitiParesi.

Teaching the mother tongue requires that the indigenous teacher has mastery of the knowledge of the culture of his people, as it is designed to teach students comes from stories, beliefs and rituals. In this way, the cultural events that take place in the village are 
already previously included in the school calendar. An example of this is when the girl's party takes place in the village and everyone participates, the teacher chooses the theme and draws up his lesson plan, according to the events. Activities such as text production, reading, sentence and word formation are carried out, as well as the meanings of the ritual that are done in the experience, at school, and in communion with the whole community.

We reaffirm that with discipline, but, fundamentally, through the mother tongue is that the Haliti-Paresi indigenous people strengthen their own language and spiritual culture. It is at school as content, discipline, but it is Haliti-Paresi spirituality itself, in songs, rituals, blessings, etc. In these experiences, young people and children Haliti-Paresi learn to value the ancient knowledge of their people and prepare to make them live, so that they pass on to other generations, making sure that they never forget Haliti culture and values. -Paresi.

As we said before, the mother tongue is a subject and it is used in all stages of schooling of Haliti-Paresi children and young people. Thus, we consider the Zozoiterô Indigenous Municipal School to be specific and differentiated and intercultural, as it was and is thought and rethought based on the reality of the Haliti-Paresi indigenous people. It is in accordance with the understanding of the teachers (as) Haliti-Paresi, because it dialogues, negotiates and works a range of the context itself, as well as the westernized, universal context.

It is essential for the Zozoiterô Indigenous Municipal School, the literacy of children, adolescents and young people in the native language of the people, because, in addition to being speakers, they need to learn to read and write in the original language, to know and to learn Halitic spelling and grammar. Paresi, so that they can produce text in the Haliti-Paresi language.

The native language Haliti-Paresi has great significance for the people, it is part of the traditional festival, offering, sacred flute, sacred arrow, blessing, history, txihyali, dance, prayer, among other things that are part of the culture. It is through the mother tongue that the shamans, the elderly and the elderly make the request in prayer, blessing and offering and calls on special occasions and in the bad moments of our daily lives, because it is through it that we ask for our protection for our great protector Enore (God).

Literacy takes place in the Haliti language, all explanations are made in the mother tongue. Teachers teach students with the context of the people themselves. The HalitiParesi way of life is presented and the children learn the words in their own language. For example, when it comes to animals such as kolota, zotyare, hozore, history is told, their meanings in culture are spoken of, children are used in an illustration. You are taught to 
write in your mother tongue, because children already know how to speak. Literacy in the mother tongue, as well as, the teaching of the mother tongue happens as already explained, with the selection of themes of the culture of the Haliti-Paresi people. According to Brazil (1999), the mother tongue is the language of oral instruction in the curriculum, used in the classroom to work on different concepts. She is the mediator of understandings of the indigenous worldview and also of the learning of the nonindigenous world.

These are selections from the cultural context of the Haliti-Paresi people themselves, with small children working on words, teaching them to write. In the initial years, the mother tongue is used more and in the final series more the Portuguese language. Children begin to study and become literate at the age of 6 . The mother tongue is the most widely spoken in class, teachers use their mother tongue to explain the content we teach during classes, that means, it is the language of instruction. The contents cover the cultural complex and also some universal knowledge. We have our own alphabet, which is different from Portuguese, for example: with the vowels: A: atyali (fruits); E: etseti (egg); I: iyiti (flower); O: olo (money) and U: uwi (snake).

The example given shows that even though there are selections of themes that are part of the cultural complex of the Haliti-Paresi people, there is also a persistence and influence of the alphabetical methodology associated with the words and the meanings of those words. A system influenced by Brazilian education and the beginning of school in the country. In this experimentation, a pedagogical construction mediated by elements of didactics interstituted by systemic fields of education experienced in the historical field, however, also re-signified in the methodological conduction, by being open and dimensioned by ethnopolitics.

Thus, the initial literacy and also the continuity of literacy, in the final years of Elementary Education, occur in the mother tongue and are also deepened in Portuguese, however, all support for such learning is based on the original speech, so that it mediates all the learning and writing of words. All subjects are taught in both languages, mother tongue and Portuguese.

The school, by introducing both the mother tongue and the Portuguese language in the curriculum of the indigenous school, "can help in the process of the disappearance of an indigenous language, and can also, on the other hand, be another element that encourages and favors its maintenance or revitalization. (BRAZIL, p. 119). Otherwise, writing it can mean invading in the school the "mastery of the majority language, conquering one of its most important territories" (p. 119). 


\section{Final considerations}

The reflections on the teaching of the native language Haliti Paresi and their meanings also compose learnings that are inserted in the elaboration/movement of an indigenous pedagogy Haliti-Paresi. The notes made are embodied in the experiences, negotiations, memories and incarnation of making a specific and differentiated school with its own learning.

We also point out in the reflections that we recognize the historical and significant changes regarding the strengthening of the mother tongue, and we affirm that the language is directly related to the appreciation of traditional culture among the youngest and the students. We are aware of the ongoing threats, in terms of the mother tongue, but we return to the fact that it is the strengthening of culture itself, because it is through the mother tongue that rituals, ceremonials, prayers, holy songs, songs, blessings are carried out, the pajelança, the feast of the young girl, of baptism, the offerings, the garden, hunting, fishing, in short, everything that involves the cultural and spiritual part, the worldview of the Haliti-Paresi people. This perspective demonstrates that the language of cultural meaning assumes the pedagogical place, thus, when the language assumes "the pedagogical place, it also assumes the political place and ancestral memory that defines it as an identity part of the cultural corpus of a determined people." (Ferreira, Cruz and Zitkoski, 2019, p. 43).

We understand that the school has a fundamental role in this process, together with the school community. It is hoped that we will actually have the production of teaching materials, since the Haliti-Paresi people have many records of organizing pedagogical works with content in their mother tongue. As Brasil (1999) points out, the pedagogical organization of indigenous peoples has been guided by the preparation of the study, research and the production of records that assist us in pedagogical practices. There is the intention of publications, because we believe that it is important for future Haliti-Paresi generations, because the mother tongue is the essence and identity of a people.

We recognize that the participation of indigenous teachers in intercultural teacher training has increased the perspective of valuing and strengthening specific, differentiated and bilingual education, starting at school. However, we also know that these formations are the result of the struggle waged by many peoples from the country. Still within all these considerations, we want to show that talking about teaching native language at school is always a challenge, and even more so, talking about indigenous literacy, as it is not a single literacy, it is literacy that is part of literacies indigenous, because they are specific and differentiated. 


\section{Obevisto}

For now, we finish this reflection, with many questions, and we understand that it is necessary to make definitions of public policies and studies/research that refer more strongly to literacy processes within indigenous communities, in order to, in observance and experience, record and produce new experiences.

Finally, we quote Freire with the pedagogy of the oppressed (2011) and autonomy (1996), recognizing that indigenous pedagogies are intended to be autonomous. And we remember that it is necessary to recognize that we all have the right to the territory, to specific, differentiated, intercultural, bilingual or multilingual education, that we are entitled to our original language. That through indigenous pedagogies and the maintenance of the Haliti-Paresi language, we can produce an emancipatory education with historical awareness and critical interculturality.

\section{References}

BRASIL. Estatuto do Índio. Lei nº 6001 de 19 de dezembro de 1973.

BRASIL. Constituição da República federativa do Brasil, 1988.

BRASIL. Referencial Curricular Nacional para a Educação Indígena. Brasília: MEC/SEF, 1999.

CANDAU, Vera Maria. Direitos humanos, educação e interculturalidade: as tensões entre igualdade e diferença. Revista Brasileira de Educação v. 13 n. 37 jan./abr. 2008. Disponível: https://www.scielo.br.

FERREIRA, Waldinéia Antunes de Alcântara. Produções de sentidos: movimentos decoloniais na vivência do Programa Institucionalizado de Iniciação à Docência. RELVA, Juara/MT/Brasil, v. 7, n. 2, p. 63-73, jul./dez. 2020.

Ferreira, W. A. de A.; Cruz, M. C. da \& Zitkoski, J. J., Mulheres Kawaiwete e Nambikwara: Guardiãs da língua materna. In Ferreira, W. A. de A.; et al. (Org). Mulheres e Identidades: Epistemologias do Sul - Mulheres, Territórios e Identidades, vol. 3. Curitiba: CRV, 2019, p.37-45.

FREIRE, Paulo. Pedagogia do oprimido. 50. ed. São Paulo: Paz e Terra, 2011.

FREIRE, Paulo. Pedagogia da Autonomia: Saberes necessários à prática educativa. São Paulo: Paz e Terra, 1996.

GRANDO, Beleni Salete Grando. Movimentos Indígenas do Brasil: a cultura autoritária e preconceituosa e a Educação Física. Motrivivência: Ano XI, 14, Maio/2000. Disponível: periódicos.ufsc.br.

HALITI-PARESI. Plano de Gestão-Haliti-Paresi: Território Indígena Haliti-Paresi. Mato Grosso-Brasil, 2019.

KEZONAZOKERO, Tereza Cristina. O ensino de língua materna na escola da aldeia Rio Verde: preservação e fortalecimento. Barra do Bugres: Unemat/Faindi, 2020. Trabalho de Conclusão de Curso, 2016.

MARTINS, Daniel Valério. A intraculturalidade nas comunidades indígenas da região metropolitana de Fortaleza-CE Brasil: caminho para o desenvolvimento e sobreculturalidade. Tese doutorado. Facultad de Ciencias Sociales de la Universidad de Salamanca, 2015.

MARÍN, José. Educação e Interculturalidade: Conhecimentos, saberes e práticas descoloniais. In: CECHETTI, Elcio e POZZER, Adecir. Educação e Interculturalidade: Conhecimentos, saberes e práticas descoloniais. Blumenau: Edifurb, 2014, p.45. 
MARTINS, Daniel Valério. Conceitos de Contatos Culturais e de Intervenção Social que Incidem na Sociedade Latino americana do Século XXI: Intra, Multi, Inter, Trans e Sobreculturalidade. Revista Pluri - Vol. 1, No 1 (2018)

MONTE, Nietta Lindenberg. Política Pública e Educação Escolar indígena no Brasil. In: Conferência Ameríndia: tecendo caminhos da educação escolar. Anais do Congresso de Professores Indígenas do Brasil. Cuiabá-MT: Secretaria de Estado de Educação Escolar Indígena de Mato Grosso, 1997.

NAZKEMAI, Elismara Cristina. A importância da Língua Materna para o povo Haliti Paresi. Aldeia Rio Verde, Tangará da Serra/MT. SEDUC/ Magistério Intercultural Kamahiye, 2018.

PAES, Maria Helena Rodrigues. A questão da língua na escola indígena em aldeias Paresi de Tangará da Serra-MT. Revista Brasileira de Educação. Set/Out/Nov/Dez 2002 No 21. Disponível em: https://www.scielo.br/pdf/rbedu/n21/n21a04.

PIVETTA, Darci Luiz. Amazônia Meridional: território deflagrado, educação Pacificadora. 1999. 249 f. Tese (Doutorado em Educação) - Instituto de Educação, Universidade Federal de Mato Grosso, Cuiabá.

SEKI, Lucy. A Linguística Indígena no Brasil. D.E.L.T.A., Vol. 15, N. ${ }^{\circ}$ ESPECIAL, 1999 (257290). Disponível: http://repositorio.unicamp.br.

VIVEIROS DE CASTRO, Eduardo. A inconstância da alma selvagem e ouros ensaios da antropologia. São Paulo: Cosac e Naify, 2002.

\section{RESUMO:}

Este artigo apresenta algumas reflexões relacionadas ao ensino de língua Materna junto ao povo Haliti - Paresi. É resultado de alguns questionamentos proporcionados a partir das aulas no Pós-Graduação Stricto Sensu Mestrado Profissional em "Ensino em Contexto Indígena Intercultural" - UNEMAT, acerca de práticas pedagógicas significativas dentro do contexto da escola específica, diferenciada, intercultural e bilíngue. Aborda o lugar da língua materna na escola e os seus complexos culturais constituídos em histórias, memórias e cultura própria. Localiza a língua materna como língua de instrução na escola, como etnopolítica linguística e como fator fundamental da identidade étnica.

PALAVRAS-CHAVE: Língua Materna; Haliti Paresi; Cultura.

\section{RESUMEN:}

Este artículo presenta algunas reflexiones relacionadas con la enseñanza de la lengua materna con el pueblo Haliti - Paresi. Es el resultado de algunas cuestiones aportadas desde las clases de la Maestría Profesional de Posgrado Stricto Sensu en "Enseñanza en Contexto Indígena Intercultural" - UNEMAT, sobre prácticas pedagógicas significativas en el contexto de la escuela específica, diferenciada, intercultural y bilingüe. Aborda el lugar de la lengua materna en la escuela y sus complejos culturales constituidos en historias, recuerdos y la propia cultura. Sitúa la lengua materna como lengua de enseñanza en la escuela, como etnopolítica lingüística y como factor fundamental de identidad étnica.

PALABRAS-CLAVES: Lengua materna; Haliti Paresi; Cultura. 